\section{Ag committee labors over labeling}

Messages about biotechnology and agriculture were decidedly mixed during two days of hearings in early October before the US Senate Agriculture, Nutrition and Forestry Committee. The hearings were convened by Senator Dick Lugar (R-IN), who calls the public debate over this technology in Europe "particularly bewildering" and says that concerns there appear to derive from "cultural aversion to the idea of biotechnology and food" rather than from "scientific evidence of risk."

However, Representative Dennis Kucinich (D-OH) told the committee he plans to introduce a bill in the House of Representatives requiring a label for foods that are genetically engineered. Another witness, Mark Silbergeld of Consumers Union (Washington, DC) said that labeling is needed to guarantee consumers a right to choose between engineered and unengineered foods. But representatives from several organizations, including those representing the biotechnology industry as well as major agricultural and food-producing trade groups, urged that labeling not be imposed on such foods. And, weighing in for the first time on these issues, the National Grain and Feed Association (Washington, DC) agreed that labeling is not required but recommended development of new testing technologies to detect biotechnology enhancements in products as a way of providing "the marketplace with tools. . .to minimize market-flow impediments and associated market risks."

\section{Pro-GMO ministers sidelined}

The October ministerial reshuffle of the UK government has sidelined two of the most vociferous supporters of genetically modified food. Jack Cunningham, the "Cabinet Enforcer" charged with the responsibility of aligning policy across the different government departments, has resigned and been replaced by Mo Mowlam, formerly the Northern Ireland secretary. Although Cunningham is a member of the Soil Association-the UK's organic farming umbrella-he had nevertheless held the government's supportive line that GM food was safe and that large-scale tests to assess environmental safety should continue unhindered. The other loss is Jeff Rooker, formerly the food minister at the Department of Agriculture, Fisheries and Food, who has now been transferred to the Department of Social Security. He was a staunch defender of science-based approaches to the regulation of GM foods.

One of Cunningham's last acts was to back a "peace plan" over the issue of GM food and crops. Monsanto, a number of environmental and consumer groups, and the Cabinet Office have agreed to enter a dialogue chaired by the Environmental Council, a charitable organization that aims to bring stakeholders in controversial green issues together. That dialogue is likely to be a slow process: preparatory meetings held in the last few weeks have done little more than pave the way for a bigger meeting in the spring.

\section{Anti-GMO protest spreads to cloning}

Life, a UK anti-abortion group, has called for a boycott of Sainsbury supermarkets in the UK after comments supporting research into human therapeutic cloning made by Lord David Sainsbury, former chiarman of the supermarket group. Sainsbury, now the UK's minister for science, was speaking at a fringe meeting at the Labour party's annual conference at which the topic had been raised in a presentation by Simon Best of Geron Biomed (Roslin, Scotland).

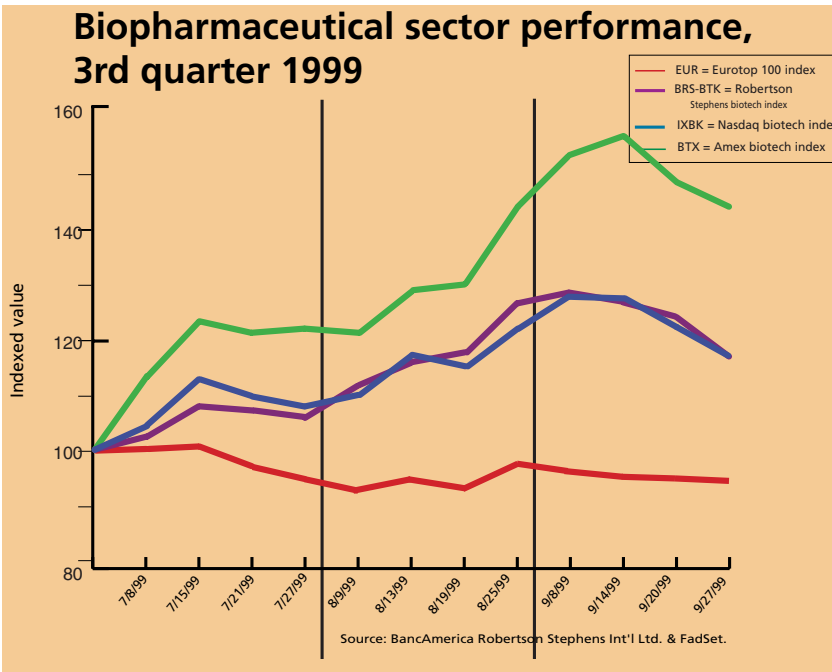

Initial public offerings, 3rd quarter 1999

The third quarter saw 3 IPOs, raising a total of $\$ 110.9$ million.

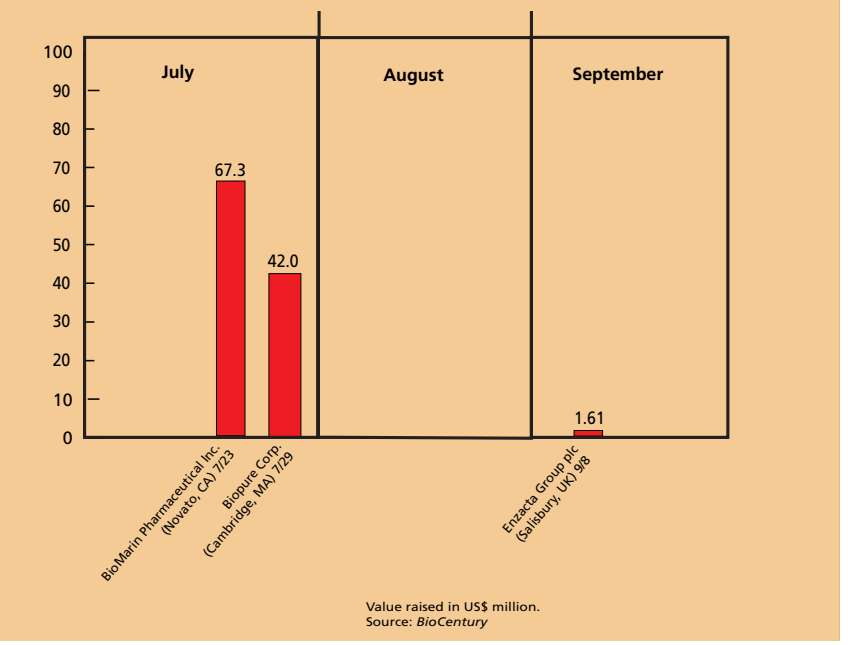

\section{Genomics companies strike a deal}

Cooperation rather than competition was apparent in genomics at the beginning of October when Millennium Pharmaceuticals (Cambridge, MA) announced nonexclusive access agreements to two databases and genomic tools from Incyte Pharmaceuticals (Palo Alto, CA) and Lexicon Genetics (The Woodlands, TX). While Incyte's LifeSeq Gold database contains around 140,000 human genes, including 50,000 novel genes not available in the public domain, Lexicon's Human Gene Trap Database encompasses thousands of commonly and rarely expressed genes not represented in other databases. Millennium characterized the arrangement as a way of accelerating its access to the complete set of human genes without compromising the company's drug discovery and development efforts. Incyte sees the deal as a milestone in its efforts to sell database access to biotechnology companies as well as to larger companies. Incyte may need new clients as its genomic information becomes commoditized by public genome efforts. Analyst downgrades hit the company's stock price (down nearly 25\% to near its yearly low value) at the beginning of October as an earning forecast showed that revenues were down despite the expansion of many of Incyte's database arrangements with large companies. 